\title{
Headlines Worldwide Pay and Benefits
}

\author{
Compiled and written by Towers Perrin
}

\section{Brazil}

\section{Study faults management of insured retirement plans}

There is plenty of room for employers in Brazil to improve the day-to-day management of their privately insured retirement programmes, according to a new Towers Perrin study. The study, based on a survey of 31 companies sponsoring insured retirement plans in Brazil, found the following:

- Companies may be paying asset management fees and administration charges above current market levels.

- In some cases, companies don't conduct a periodical analysis of the plan approach, resulting in a lack of alignment between the programme design and the company business strategy. Nearly a third of the employers surveyed indicated that their retirement plan is not meeting corporate objectives or isn't properly aligned with those objectives.

- There is limited understanding of the impact on retirement plan benefits of the actuarial assumptions adopted by insurance companies. More than three-quarters of respondents reported to have below average or no knowledge at all of the technical issues associated with plan financial management. Actuarial factors that determine whether benefits for participants in the future are higher or lower can vary greatly from one provider to another.

- Insurance contracts do not often receive a careful review by the sponsoring companies after plan implementation: almost two-thirds of companies said that contracts were never reviewed or they had only average knowledge about the contractual terms. Competition has forced administrative charges to drop from more than 10 per cent of contributions in the 1980 s to less than 2 per cent of contributions credited to the plan in 2003 .

- Insurance companies dedicate very little attention to employee financial education, indicating that employees who participate in $401(\mathrm{k})$-like retirement plans are probably not getting the full value of those programmes. The great majority of employers said that their providers give them only basic, little or no information on plan investments.

Towers Perrin has set up the Coalition of Companies Sponsoring Insured Retirement Plans in Brazil to assist employers in managing their retirement programmes more effectively as well as providing access to competitive information and analysis.

Further information: Eder Carvalhaes, São Paulo, eder.carvalhaes@towers.com. 


\section{Towers Perrin survey highlights shifting executive pay practices}

Employers in Brazil are shifting to more sophisticated pay practices to measure performance when setting remuneration levels for high-level executives, according to a new study by Towers Perrin. The study, Compensation Strategies for Top Executives in Brazil, is based on a survey of nearly 100 employers based in Brazil, and focuses on pay practices for chief executive officers and their direct reports.

Here are some of the study's main findings.

- Companies with the best results and performance levels tend to have higher base salary, bonus and long-term incentive (LTI) programmes. These companies also typically have sophisticated bonus programme designs based on indicators of economic value creation, with wider payout ranges and more weight placed on business unit measures.

- Bonus programmes have undergone frequent adjustments in an attempt to better align incentives with business strategies and results. These changes include a greater use of operating performance indicators (eg EBITDA, cash flow), higher target reward levels and goal-setting based on results achieved by peer companies and the cost of capital. At the same time, there is less reliance on plan indicators that are subject to accounting adjustments.

- Approximately half of the companies surveyed adjusted their bonus programs to qualify for Law 10.101, which exempts qualifying profit-sharing programmes from government taxes.

- Local Brazilian companies tend to have higher base salary and bonus levels than subsidiaries of foreign companies, which offer more generous executive perquisites and make greater use of LTIs, especially stock options.

- Roughly half of the surveyed companies exclude executives from salary increases granted in union agreements. Within this group, salary raises are based exclusively on performance and market conditions, not on union negotiations.

Further information: Felipe Rebelli, São Paulo, felipe.rebelli@towers.com or Eduardo Martins, São Paulo, eduardo.martins@towers.com.

\section{Czech Republic}

\section{Government seeks to liberalise pension fund investment rules}

The Czech Government is seeking to expand investment opportunities for private pension funds and align them more with European Union standards. Under legislation that is now before the parliament, private pension funds would be allowed to invest in domestic and foreign open-end mutual funds.

Currently, they can invest only in foreign bonds.

The government proposal also includes provisions that would allow pension plans to have up to 10 per cent of their assets in real estate and 5 per cent in instruments at the discretion of the plan sponsor. In addition, a new government regulatory agency with stricter oversight powers would be created, taking over the role from the Ministry of Finance. Employees from the EU working in the Czech Republic but not residing there would be able to participate in Czech funds.

The Czech private pension plans were started in 1994 to supplement the state-run system. Employers and 
employees can choose to contribute on a voluntary basis to the private funds, which are subsidised by the government. There are currently 13 authorised funds, the number having declined in number in recent years due to industry consolidation.

Further information: Jeff Schwartz, New York, jeff.schwartz@towers.com.

\section{European Union}

\section{Pensions directive wins approval}

The European Council of Ministers has given final approval to the pension funds directive that sets standards for the prudential supervision of pension plans in the EU (see 'Headlines', Pensions, Vol 8. No. 4, pp. 379-80). The directive, which was adopted on 13th May, 2003, covers employer-sponsored, separately funded pension plans. It does not apply to book reserve or to pay-as-you-go plans.

Individual member states have two years to introduce domestic legislation implementing the provisions of the directive. The extent of the changes required will depend on each member states' current laws, but key areas that could impact on company-sponsored pension plans include the following:

— Investment restrictions will be liberalised. Plans will be required to invest their assets in line with the prudent person principle, although some quantitative investment limits can be retained up to certain ceilings.

- Minimum actuarial and funding standards will be imposed. Individual member states have some flexibility in prescribing these standards.

- Financial and other information must be given to plan members each year. This includes the funding status of the plan - a particularly relevant requirement given the reduced funding levels prevailing in most countries.

The directive also introduces a framework for cross-border pension plans, although the tax treatment of these plans remains a controversial issue that is being tested in the EU courts.

Further information: Karen Klietz, London, karen.klietz@towers.com.

\section{Officials step up campaign against pension tax discrimination}

European countries are under increasing pressure to end tax policies that discriminate against foreign pension funds.

The European Commission has decided to take Denmark to the European Court of Justice and has started infringement proceedings against the UK and Ireland. In February 2003, the Commission issued a 'reasoned opinion' to the Danish Government asking that it change its tax policy so that pension contributions paid to pension funds located in other member states are tax deductible on the same basis as contributions paid to domestic pension funds. So far, the Danish Government has not done so.

In addition, requests for information (the first stage in infringement proceedings) have been issued to the UK and Irish Governments. These centre on the requirement that company-sponsored pension plans set up to qualify for tax-favoured status must have a UK or Irish representative to fulfil certain duties in the trust arrangements that apply to these plans. In February requests were also sent to Belgium, Spain, France, Italy and Portugal, although the outcome is not known because the proceedings are confidential.

In a separate move, the Commission has issued requests for information to 
Germany and Austria about what it considers discriminatory tax treatment between domestic and foreign investment funds. France has also received a request for information in relation to its tax treatment of shares.

\section{Skandia ruling}

The European Commission is determined to stamp out tax discrimination against European based non-domestic funds, which it considers a violation of EU law on the freedom to provide services and the free movement of workers and capital.

This view is supported by the European Court of Justice, which in its latest judgment in the Skandia case ruled that it is unlawful for member states to discriminate between the tax treatment of pension contributions to foreign and domestic insurance-backed pension plans. The case, brought on behalf of the Skandia insurance company and a Swedish employee, is based on Article 49 of the European treaty, which protects the freedom to provide services across the EU.

Under Swedish law, employers are able to obtain an immediate tax deduction for contributions made to a pension insurance contract taken out with a domestic insurer. However, if the contributions are paid to a non-domestic insurer, the employer can only claim a tax deduction on the payment of benefits when they are actually paid to the employee. In both cases, the employee is taxed only on the benefits when they come into payment. The Court ruling prohibits the Swedish Government from applying less favourable tax treatment to pension contributions made to a foreign insurer than applies to a domestic insurer.

It remains to be seen how quickly member states will take steps to remove these tax barriers. In the UK, a ruling is still awaited from the UK tax authorities on the AMS case that involves a proposal to include a UK employee in a Dutch pension plan.

These developments are, however, a step on the road to tax harmonisation. The removal of discriminatory tax treatment is expected to encourage multinational employers to develop a more pan-European approach to their pension policies and assist the design of pension policies for internationally mobile employees.

Further information: Karen Klietz, London, karen.klietz@towers.com.

\section{Ireland}

\section{Government increases minimum severance payments}

Higher minimum severance (redundancy) payments are now in effect in Ireland following approval of government-backed legislation by Parliament.

Under the new law, employers must give terminated employees at least two weeks of salary for every year of service regardless of age. This is a change from the previous practice of giving departing employees under the age of 41 half a week's pay per year of service, and those aged 41 and older one week's pay per year of service. Employers must continue to make bonus payments for an additional week.

Statutory redundancy payments in Ireland are only a portion of the complete severance package that most employers typically grant to departing employees. It is common practice for employers to make payments ranging from three to as much as seven or eight weeks' pay per year of service in some cases for highly paid employees.

Supporters of the legislation said it was their intent to increase the statutory minimum for payments rather than 
increase the overall cost of severance packages made by employers.

Accordingly, the change in law is not expected to impact the cost of severance programmes for most large employers in Ireland.

The law also makes a number of technical changes in the statutory redundancy rules. These include changes in treatment of service abroad, simpler application forms, and a streamlined process for employees of insolvent companies to submit claims for payment.

Further information: Michael Parker, London, michael.parker@towers.com.

\section{Netherlands}

\section{Coalition government proposes pension changes to support work/life balance}

The Dutch coalition government is seeking to implement a strategic policy statement on employee benefit packages, and pension plans in particular.

The agreement, which was reached in May 2003, is called Participation, More Jobs and Less Regulation, and will form the basis for draft legislation that is expected to be submitted to the Dutch parliament before the end of the year.

Key proposals are to:

- introduce a Course of Life Plan to enable employees to take a break during their career, by forgoing part of their salary and drawing on the accumulated amount during the career break. The plan will be an alternative to company savings plans, under which the limits on tax deductible contributions were reduced from 1st January, 2003;

- reduce the maximum allowable accrual rates for qualified company-sponsored pension plans from 2 per cent to 1.75 per cent a year for final-pay plans and 2.25 per cent to 2 per cent for career-average plans, as stipulated in a previous agreement by government coalition partners. The resulting tax savings will create the budget needed for the tax-qualified Course of Life Plans. The restriction is likely come into effect beginning 1st January, 2004, although existing plans will have until 2006 to comply;

- abolish qualified company-sponsored VUT (early retirement) plans and other early retirement pension plans in a phased transition of 20 years;

- reform the state disability and unemployment benefits.

In addition, the government has called upon the social partners (private-sector employers and employees' unions) to limit wage increases under their collective labour agreements in accordance with the restrictions now imposed on public sector workers. At the same time the government has announced that the pension reforms will be implemented after consultation with the social partners.

Further information: Adriënn Pásztor Amsterdam, adrienn.pasztor@towers.com.

\section{Tax authorities revise maximum defined contribution tables}

Employers operating defined contribution plans in the Netherlands will need to review the amounts paid into the plans following the publication of revised maximum contribution tables by the Dutch tax authorities.

The revised tables came into force on the publication date of 28th April, 2003 and replaced tables published in 2000.

Under Dutch law, both employee and employer contributions to defined contribution plans are tax deductible, provided the amounts are consistent with the tables published by the Dutch tax authorities. These tax tables show in 
five-year age bands the maximum contributions that can be paid as a percentage of earnings (up to the current earnings limit) for the different types of pension. (For example, there are different tables for individual life and for joint survivors pensions.)

The new tax tables are intended to make a number of clarifications and to cover some previous omissions.

However, they do make a number of fundamental changes to what was previously understood. In particular, they:

- make it clear that where plan contributions are below the maximum, they must be proportionally below the maximum at all ages;

- specify that where administration costs are payable separately, the contribution percentages are reduced accordingly;

- include a new explanation for calculating contributions to a bridging pension (a temporary pension payable between retirement and state pension age) that is likely to reduce the size of allowable payments.

There are no transitional provisions for existing plans. Therefore companies should review their plan's contribution tables as soon as possible and make any necessary adjustments.

Further information: Adriënn Pásztor, Amsterdam, adrienn.pasztor@towers.com.

\section{New Zealand}

\section{Lower earners get better tax treatment on employer pension contributions}

Lower wage earners will be receiving a greater share of the retirement plan contributions by their employers as a result of a change in tax rules recently announced by the government. The change will not impact the overall cost of these plans to employers.
Under New Zealand law, contributions by employers to retirement plans (superannuation schemes) are subject to a withholding tax at the rate of 33 per cent for all employees. This means that they receive $\$ 67$ out of every $\$ 100$ paid to the plan. When the top marginal tax rate increased in 2000 to 39 per cent, highly paid employees got a small advantage while employees at the other end of the income scale on a marginal tax rate of 21 per cent continued overpaying the tax on their employer contributions.

In its May 2003 budget, the government sought to address this inequity and announced that beginning on 1st April, 2004, the withholding tax for those earning less than $\$ 38,000$ a year will be reduced to their marginal rate of 21 per cent. For a typical employer contribution of 7.5 per cent of earnings, up to an additional $\$ 342$ per year will be paid into the plan for each employee. An estimated 100,000 plan members will benefit by the change.

Employers will need to ensure their administrative systems can cope with the change, although exact details have yet to be announced. One important unresolved issue is how to make the change in defined benefit plans because the employer contributions are not designated for any particular employee. The government is discussing the issue with the Society of Actuaries and other industry groups.

Further information: Mark Weaver, Wellington, mark.weaver@ mjwactuary.co.nz.

\section{Spain}

\section{Tax barrier to group insurance contract transfers removed}

A new tax law in Spain will make it more financially viable for sponsors of retirement plans funded through group 
insurance contracts to switch insurance companies.

Law 46/2002 took effect on 1st January, 2003, and makes clear that there is no tax payable on transfer payments from one group insurance contract to another. Transfer payments from a group insurance contract to a qualified company pension plan are taxable.

The old law was unclear, and insurance companies, without having any specific instructions from the tax authorities, preferred to be conservative and avoid any potential problems by applying a 15 per cent tax on any transfer payments. The government decided to clarify the law because it considered the practice a disincentive for pension fund transfers and therefore a barrier to competition among insurance companies. The new law applies to both company and individual employee transfers of funds.

The new law should encourage plan sponsors to review their existing group insurance contracts with a view to obtaining better terms either by renegotiating the terms of their existing contract or transferring to a new insurer. They will, however, need to consider other factors, such as the size of any surrender penalties applied on transfer or any other specific contract provision regarding surrender rights. It is also possible that the new law will encourage employees to request transfer payments from their former employer's retirement plan to their current employer's plan, especially if they believe the terms are more favourable.

Further information: Elena González, Madrid, elena.gonzalez@towers.com.

\section{Sweden}

\section{New pension accounting standard to impact Swedish companies}

Publicly traded companies in Sweden will need to assess how they will be affected by a new accounting standard for employee benefits issued by the Swedish Accounting Board (Redovisningsrådet).

Subsidiaries of Swedish public companies located elsewhere will also need to report under the new accounting standard. For example, the new standard will apply to Swedish companies operating in the USA that have been using US generally accepted accounting standards (GAAP).

The new standard, called RR29, is based on the international accounting standard IAS 19 and takes effect from 1st January, 2004, although some companies have already adopted it. It will replace the existing standard, FAR 4, but only at a group accounting level.

RR29 is intended to make the calculation of the pension liabilities more consistent and to facilitate comparisons between one company and another. Companies sponsoring defined benefit plans will be most affected because the new standard, like IAS19:

- uses corporate bond rates to discount the value of pension liabilities instead of the constant discount rate under FAR 4;

- increases the value of benefits in line with a future salary increase assumption. FAR 4 uses current salary, although a buffer is included;

- uses a single basis to calculate group pension liabilities for multinational employers. FAR 4 allows the pension liabilities of non-Swedish companies to be taken as the amount reported under their own country's accounting rules.

The introduction of the new accounting standard is expected to have a major financial impact on some large groups doing business in Sweden. A few groups 
that already applied RR29 as of 1st January, 2003 saw their equity reduced by at least SEK 1 billion.

Further information: Caroline Grégoire Engberg, Stockholm, caroline.gregoire. engberg@hrs.se or Mats Hgglund, Stockholm, mats.hagglund@hrs.se.

\section{United Kingdom}

\section{Government sets new limits on pension plan terminations}

The UK Government has acted to prevent solvent employers from terminating their defined benefit pension plans and walking away from the liabilities.

In the UK, when a plan is terminated, the available assets are normally used to buy the accrued benefits of members through individual insurance policies. However, in today's financial climate, most plans do not have sufficient assets for a buyout, and the employer is legally obliged only to meet any shortfall up to a certain level that falls far short of the buyout cost.

At least one major employer has chosen to terminate its UK pension plan, leaving the plan with insufficient assets to buy all members' benefits. With speculation that a number of others were going to follow suit, the government is soon expected to pass new regulations that will require solvent companies to meet the full buyout cost. However, if payment would put the company itself at risk, the plan trustees could agree a lower amount. The regulations will apply to any plan that starts to terminate after 10th June, 2003.

A further change expected to be implemented by the end of this year will give non-pensioners, particularly those with long service, a more favourable allocation of plan assets when a plan is terminated.
These actions are part of the government's proposals for pension reform, following its green paper issued in December 2002. In these latest proposals, the government has focused on measures to make it more likely that benefits promised to members of company-sponsored pension plans will actually be delivered, especially those not yet receiving their pension. At the same time, the government is taking steps intended to reduce the burden on employers.

Other proposals expected to come into force in 2005 include:

- establishment of a pension protection fund (similar to the Pension Benefit Guarantee Corporation in the USA) to guarantee members' accrued benefits under defined benefit plans when an employer becomes insolvent. The fund will be financed by premiums from the plans themselves;

- creation of a plan-specific funding standard to replace the current statutory minimum funding standard for defined benefit plans.

Employers with defined benefit plans will need to consider whether in the light of these proposals they need to revisit their current benefit and funding strategy. Issues about the potential liabilities will also need to be considered by companies involved in mergers and acquisitions.

Further information: Clive Briggs, London, clive.briggs@towers.com or Karen Klietz, London, karen.klietz@towers.com.

\section{USA}

\section{FASB moves to step up pension disclosures}

The Financial Accounting Standards Board (FASB) has tentatively decided to 
amend FAS 132 to require employers to disclose additional information that could be used to evaluate the risks associated with a company's pension assets, benefit obligations and pension cost. The changes are in response to appeals from the investment community for greater transparency in financial reporting about pension plans.

The added disclosures would focus on areas that may affect future earnings and cash flow, specifically:

- asset mix;

— targeted asset allocation;

- expected rate of return for each type of asset;

- voluntary and required contributions expected to be made in the next year;

- the timing and amount of future benefit payments;

- where pension costs have been reported on the income statement.

In addition, the FASB plans to require companies to disclose the following in their quarterly financial statements: components of pension cost, the income statement classification of the net pension cost, and significant changes in contributions or expected contributions from what was previously disclosed. Still to be decided is whether these additional disclosures would also apply to other post-retirement benefit plans.

The FASB plans to issue an exposure draft of a proposed FAS 132 amendment in August 2003 for public comment. A final statement is expected before the end of the year and would be effective immediately.

The additional disclosures may increase scrutiny of the expected return on assets assumption used to determine pension cost. In addition, depending on the actual requirements, identifying where pension cost has been reported could be a time-consuming and complex process for plan sponsors.

Further information: Diana Scott, New York, diana.scott@towers.com.

\section{Accounting board to examine treatment of stock options}

The FASB has added a project to its agenda to re-examine the accounting treatment for stock options and other stock-based incentive programs in the USA. Currently, employers are required to disclose a pro forma measure of compensation cost based on the fair value of option grants and awards, but they are not required to expense stock-based awards on that basis.

The FASB said it hopes to work closely with the International Accounting Standards Board (IASB) to achieve the maximum degree of 'convergence' between the US and the international standard. The IASB's proposed rules, which would require expensing the fair value of stock-based awards, are expected to take effect in 2004, and members of the European Community are generally required to adopt the International Accounting Standards by 2005.

Further information: Diana Scott, New York, diana.scott@towers.com. 